\title{
Folklore and Folk Songs of Chittagong: A Critical Review
}

\author{
Amir Mohammad Khan \\ Department of English, Bangladesh Army University of Science \& Technology(BAUST), Saidpur, Bangladesh \\ E-mail: amir_khan.chu@yahoo.com
}

Doi:10.7575/aiac.alls.v.8n.2p.37

URL: http://dx.doi.org/10.7575/aiac.alls.v.8n.2p.37
Received: 12/01/2017

Accepted: 27/02/2017

\begin{abstract}
Folk Songs stems from Folklore are very rich in the southern region of Chittagong. In this part of the world Folk Songs play pivotal role in the lifestyle of people as a heart-touching and heavenly connection exists between human, nature and Folk Songs. Folk Songs in this area are special because we found the theme of Nature Conservation in them. We took the southern part of Chittagong (Lohagara, Satkania, Chandanaish and Patiya) as our research area, selected a village namely Chunati in the systematic sampling and more than 100 people were interviewed through focus group discussion and key informant interviews. The sufficient literature review is also done. People in this area love nature a lot. Here music personnel were born from time to time who not only worked for the musical development but also created consciousness among people to love nature and save it. We discussed about the origin of Folk Songs, pattern of Folk Songs to clarify the importance of Folk Songs of Chittagong for its connection to Folklore and at the same time for promoting the idea of Nature Conservation. Of course, this part of studies deserves more attention in the field of research. Our ultimate goal should be to conserve and promote Folk Songs of Chittagong with yearlong heritage that automatically will later enrich Folklore and Nature Conservation.
\end{abstract}

Keywords: Folklore, Folk Songs, Nature Conservation, Chittagong, Heritage

\section{Introduction}

Folklore, though a very much discussed topic, Folk songs of Chittagong may be a deprived chapter in the field of research. Being a student of literature we found this part of research to be an interesting one. Moreover, it is also natural that Human loves tune and music and a research on music should be a better one than the commonly interesting topics like Shakespeare, Shelley and Keats. Most of the participants in the survey are of views that Folk songs of Chittagong are rich with aesthetic values and they should be conserved like other Folk songs in the various parts of the country. From our survey we also collected various songs and Folklore from the solid interviews and we here tried to discuss these on a small scale. Our discussion will focus on the Folklore and Folk songs of Chittagong to critically show the literary and artistic value of these and bring about a change in the brain of the researchers to conserve these songs understanding their yearlong contribution to the development of society, culture and heritage. Literally, people of the southern part of Chittagong cherished their songs and nature at the same heart. We remarkably found their spirit to conserve the nature in their songs. In this way, the lyricists and the song makers contributed to the conservation of nature from time to time.

\section{Origin and Pattern of Folk Songs}

Back of all literature sketches an unmapped and immeasurable world of oral tradition which may roughly be called Folklore. As in other countries in the world in Bangladesh we also can discover an enormous amount of influence of Folklore on our old and modern Bengali Literature. The songs of Bangladesh especially got evolved from Folk Songs. The development of music that we observe today-we could contemplate on newer tunes, the source of all these is basically Folk Songs. Human one day found tune in the sound of birds and sweet notes of river. Its joy-sorrow and love's tone turned to language in heavenly garden of nature; in the sacred touch of wind-in the tone of birds. Songs inherently came up from heart. In this our soil-human-song there is variety in it, there is the taste of mixed thinking, there is the colour of some special land. In the singing style as well there is the variety. Like the sky-sun-moon-star, river-wind, the smell of paddy and tune of birds, in this non-communal country many Folk Songs are the collective thought of Hindu-Muslim-Buddhist and Christian and the source of the fulfillment of practice and equity. These songs do not belong to one religion or one community ${ }^{1}$-these songs are a property of the people of whole Bangladesh, the rhythm of love from its core of heart. It is, however, worth quoting Rabindranath Tagore in regard to explaining the intertwining relationship between literature and the idea of Nature Conservation.

"I tried my best to develop in the children of my school the freshness for their feeling for nature, a sensitiveness of soul in their relationship with their human surroundings, with the help of literature, festive ceremonials and also the religious teaching which enjoins us to come to the nearer presence of the world through the soul”.'(Rabindranath)\{Shipra Shorkar, 2008, p.47\} 
3. Setting, Culture and Heritage of Chittagong

Chittagong is known as the queen of the East. It is an important district of Bangladesh. The geographical variety made this district to be a unique place. Hills, sea, landscape, forests etc all these heavenly beauty made this district to be a naturally beautiful garden. "I will take you to the riverside, take you to the forest; visit all to your content; sing to your mind's happiness. I will remain with you; tell me your inner talks”. (Lyricist Shaheed Mahmud)\{Tritiyo Bishsho Album, Track 2, 1993\} From the British reign Chittagong is an important place for trade and commerce. Being an important place of country's port it contributed to the development ${ }^{2}$ a lot. From the time immemorial people of various cultures congregated together in Chittagong and that's how a new generation of mixed culture is developed in this area. In the southern Part of Chittagong there are places like Patia, Chandanaish, Shatkania, Lohagara etc. People of all religions have been culturally developed in this area since the British reign. Various social programmes like 'Marriage' and 'Nabanna'3 gave birth to various local songs. The Hindu and Buddhists basically made various songs for their worship to god.

In the Muslim community the practice of songs basically evolved from the social programmes like marriage and seasonal programmes. The natural beauty and wealth gave the power to people of this region to practice and make lyrics-tunes that are really rich in terms of literary and aesthetic values. Interestingly enough, in these songs of men of soil there is the thinking to conserve the nature. People of all religions believe that their nature is a great asset for them given by the God and they feel that they should conserve this as this gives them the inspiration to live beautifully and happily.

"We can work together in a common pursuit of truth, share together our common heritage, and realize that artists in all parts of the world have created forms of beauty, scientists discovered the secrets of the universe, philosophers solved the problems of existence, saints made the truth of the spiritual world organic in their own lives, not merely for particular race to which they belonged, but for mankind.”(Rabindranath) \{Shipra Shorkar, $2008, p .44\}$

\section{Human Bond with Folk Songs}

Songs are an integral part of human life. Those who are dependent on nature depend on songs a lot. The wage earners like farmers, boatmen and rickshaw pullers sing and make songs while working in their field. In these kind of songs there are the words of life, nature, family and surroundings. It is seen that they cannot work without singing as if their all spirit and power they gain from music. In the Folk Songs of Chittagong there is the thought of general people, talk of their lifestyle. The impact of these songs over the people of all stages is so vast and it is like mixed in the blood of sons of the soil. The interlinked relationship between the standard of living of peoples and the conservation of nature and environment is also discussed in the arena of economic thought. The following quote from Adam Smith can be taken into account in this regard.

"The wealth of nation is its people. And the purpose of development is to create an enabling environment for people to enjoy long, healthy and creative lives." (Adam Smith) \{Shipra Sharkar, 2008, p. 24\}

\section{Folk Songs' Connection with Nature}

Folk Songs actually came from the thinking of nature. There is a beautiful link between Folk Songs and nature. As soon as human started loving nature he/she started writing lyrics and that's how the Folk Songs came into being. The sea, the river, trees, meadows, dawn and dusk all are found in lyrics in an aesthetic form. The development of Folk Songs therefore contributed a lot for human to come close to nature. That's how the Folk Songs became the part of life for the people of Chittagong. To them nature and their songs are like their life-blood that from time to time taught them the way of better living. The spirit of nature-loving comes from Folk Songs and that actually lead people to be aware of conserving nature. The music lovers actually love nature and they always show their keenness to preserve it. The Folk Songs created consciousness among general people to love and preserve nature and they are successful in building among people that spirit that for better living they must remain close to nature and conserve it to keep a better world for their next generation to come.

"I wandered lonely as a cloud that floats on high over the vales and hills, when all at once I saw a crowd, A host, of golden daffodils. "(William Wordsworth) \{An English Anthology, 2003, p.29\}

\section{Some Discussion on Folklore}

Folklore, actually needless to say, as explained earlier signifies the wisdom and knowledge of the people and one can discover this wisdom in traditional riddles, rhymes, charms, beliefs, superstitions, proverbs, place names, myths, tales, fairytales, legends, festivals and all other repertoire of real tradition whose medium is the spoken words, from time immemorial. Because of space limitation, we can try to give a few illustrations only.

Among the earliest specimens, we can say about riddles, which will speak about the earliest and most widespread types of formulated thoughts. What it says-that it explains when asked-

"Sakal belay char paye hate/ Dupur belay du paye hate/ Bikel belay tin paye hate deshe chole babaji/. Four legs it has in the morning/ Two legs it has in the noon/ with three legs in the evening it goes home."-MAN. (Ashraf Siddiqui, 1976, p.51) 
This is a popular riddle connected with the story of Sphinx and Oedipus. Found not only in Greece but also all over the world, including Bangladesh. In addition, the above mentioned specimen is found everywhere in our country, even in a Baul song like Lalan Shah Fakir. Is it a riddle only? Does it not say of the transient and fragile human life from its childhood to the grave? "In hundreds and thousands of riddles found in Bangladesh from as early as $7^{\text {th }}$ Century A.D. we discover physical and natural environment of Bangladesh, its people, women, birds, households and also societyand see how it melts with the time and age." (Ashraf Siddiqui, 1976, p.51)

In the evolvement of Folklore the environment and surroundings are especially effective. People get upbringing in the environment gradually. From time to time the environment purifies people through various storms and tests. As a result, the environment plays role on his characteristic, social and artistic development. This role is uniquely reflected in all stages of life. With the surroundings of human his own world is created. There are two kinds of environment-natural and cultural. The lifestyle and all activities of human is the outcome of natural and cultural environment. Owing to the difference of natural environment different groups of cultural people within and between countries are seen to develop.

The history of Folklore all over the world has brought us to the conclusion that Folklore is not limited to one country, as it is handed down from generation to generation through oral tradition. The origin of Folklore may be traced through thousands of years. The origin of Folk Songs or ballads or folk tales or riddles or proverbs which are current even in the remotest corner of Bangladesh today may be discovered in Europe, America, Persia or Arabia or Asia Minor and so on.

\section{Folk Songs}

"There are innumerable varieties of Folk Songs in the riverine Bangladesh, which are sung by different cultural groups, in different parts of the country. We had as many as 222 varieties of Folk Songs most of which are now defunct."(Ashraf Siddiqui, 1976, p. 38).

In the alienated life of current time the artists under the subconscious mindframe go back and seek relief to the creative art. And this subconsciousness very normally along with the experience of childhood and adolescence poses a reflection on the brain and heart of the artists. In this country of splendid natural beauty and soil-touched villages most of the artists are born and developed in a natural setting. In this process of development in the subconscious mind of people there is the taste of experience and loss of sweet memories. So, in this constant life cycle of human through the rough and unfavourable incidents man seek refuge. In this case, some leaving the present in the body, mind and creativity set back to the past, some again create a connection between the past subconsciousness and present consciousness and some get connected to the present and become nostalgic. In the life frame of rural people under everything, in the parallel system the practice of song making goes on without any interruption. The creative extreme emotion of love and spontaneity of the lyricists kept the Folk Songs alive tremendously. In the agriculture-based social system of Bangladesh the lyricists and singers always looked for the basic rural life-style. In the agriculture based social system parallelly the practice of lyric and tune-making is constant. The farmer-labourer-cowboy and fisher etc all the people of these classes kept up the stream of Folk Songs production side by side with their daily productive work-stream.

"As there is cultivation and canoes-the daily various activities of the villages are going on and in between there is the regular strong endeavour to sound the tune forever."(Rabindranath) \{Ashraf Siddiqui, 1976, p. 53\}

\section{Folk Songs of Chittagong and The Thought of Nature Conservation}

As stated earlier, human started writing songs from the love they adopted from their surrounding nature. The natural setting of Chittagong is beautiful for rivers, canals, hills, forests, birds, wildlife and so on. Human began writing songs here when he comes close to the rivers, trees and forests. From the very childhood people here observe the beauty of nature, become dependent on nature and gain the ultimate belief that without the nature life is impossible for them. From this point of view, nature starts coming to their writing, their tune, music and everywhere. At the southern part of Chittagong when people see that in the land and sky their nature takes new shapes in different seasons they become nature lovers and from the love of the nature they start writing lyrics that thereby turns to tune and songs with a remarkable mention of nature and their connection with it.

"In the moonlit night I will sit with you at the boat station: In the dark nights will together see the glittering of firefly; and will listen to the humming of cricket: Tell me your inner talks." (Lyricist Shaheed Mahmud) \{Tritiyo Bishsho Album, Track 2, 1993\}

\section{The Ultimate Trio-Nature, Human and Songs}

Nature gives the power and strength to the people of Chittagong in every moment. People get fuels and shelter from the forests, fish from rivers, canals and ponds, get transport easily on the river, fresh air and water, medical treatment, crops from the land and so on. Naturally from childhood people successfully develop a good relationship with nature. At the morning when a child starts going to his school he observes the change in nature very easily. He hears the birds sing, air soothes, farmers work in the field and there he finds the green and golden beauty of the field in different times, birds fly in the sky, squirrels run this tree to that tree, cattle bark- all these help this child to be acquainted with nature very easily. By the by, as he grows up his brain observes nature's all-round co-operation to him. That's how actually people become introduced and habituated with their surrounding nature. In the southern region of Chittagong the scenic beauty 
and God-gifted glamour of nature not only make man eulogize and glorify nature but also help them develop a strong love and faith for nature, an urge to save nature, a yearning to develop it.

"The waves beside them danced; but they outdid the sparkling waves in glee; A poet could not but be gay, in such a jocund company; I gazed-and gazed-but little thought, what wealth they show to me had brought." (Wordsworth) \{An English Anthology, 2003, p.29\}

\section{Recommendations}

Despite the importance of study of Folk Songs and its spirit to preserve nature still there is no sufficient research on this ground. As a result, lots of valuable songs are already lost and because of the lack of patronage the development of this kind of songs is interrupted. This is not only harmful for Folk Songs but also for the conservation of nature since it is proven that there is a good connection between nature and Folk Songs. This research will bring about a new rhythm in the development of Folk Songs and help general people to be conscious about saving the nature through their lessons from folk music.

\section{Conclusion}

In the Folk Songs people and nature is placed side by side. Folk songs not only give impetus to human to love nature but also give lesson to human to be conscious about preserving and developing nature from time to time. Naturally there is a relationship between human and nature and Folk Songs become a bridge between them. Folk Songs create devotion among us to be careful to nature as much as nature is to us. The poets, lyricists and tunists realizing the fact that nature should be kept outside any harm from being polluted, by their pen and lyrics create awareness among people that at the same time give them strong spirit for better living and be caring to nature. The nature specialists tried to make us conscious to save and develop nature on various occasions but we see that the folk lyricists did the same without any prior personal benefit rather from their authentic love of nature. On this occasion, we feel a good study on Folk Songs of Southern region of Chittagong will pave the way to a great change in our knowledge about nature and to gain sufficient inspiration to preserve and develop it sothat we may keep ahead a better world for the generation to come.

\section{References}

Ashraf Siddiqui, Folkloric Bangladesh, December 1976, Mohammad Nurul Huda, Bangla Academy Press, Dhaka, Bangaldesh.

Chowdhury Sree Purnachandra Devbarma Tatyanidhi, History of Chattagram, edited by Tapanker Chakrabarty, July 2011, Sikder Abul Bashar, Banglabazar, Dhaka, Bangladesh.

Mohammad Ahsan Khan, Bangladesher Unnayan Natya, June 2013, Dr. Abdul Wahab, Bangla Academy, Dhaka, Bangaladesh.

Nesar Ahmad, Chatgna: Chandni Prohor O Oshoririgon, February, 2004, Rehena Chowdhury, Proggalok Prokashani, Momin Road, Chittagong, Bangladesh.

Shamsul Arefin, Bangladesher Lokokobi O Lokoshahitya, February, 2007, Balaka, February Book Fair, 2007, Momin Road, Chittagong, Bangladesh.

Shamsuzzaman Khan, Bangladesher Lokooitijya, 2008, Dr. Abdul Wahab, Bangla Academy, Dhaka, Bangladesh. Syad Mohammad Shahed, Bangla Academy Folklore Sangrahamala, Volume 15, Lokochara-05, June 2010, DirectorResearch, Folklore Department-Bangla Academy, Bangla Academy, Dhaka, Bangladesh.

Momen Chowdhury, Bishay-Boichitrye Folklore, February, 2008, Mohammad Jahidur Rahman, Director-Bangla Academy, Bangla Academy, Dhaka, Bangladesh.

Motiur Rahman, Protichinta, September 2014, Motiur Rahman, Karwan Bazar, Dhaka, Bangladesh.

Onu Hossain, Bangladesher Kobita: Lokoshongskritir Nondontattya, April 2007, Dr. Abdul Wahab, Bangla Academy, Dhaka, Bangladesh.

Shipra Sarkar, Development and Rabindranath's Educational Philosophy, December 2008, Dr. Abdul Wahab, Bangla Academy, Dhaka, Bangladesh.

An English Anthology, 2003, Niaz Zaman, Fakrul Alam, K. Ashraf Hossain, Momin Offset Press, 9 Nilkhet Babupura, Dhaka, Bangladesh.

Tritiyo Bishsho Album, 1993, Renaissance, Shongita Production house, Dhaka, Bangladesh.

\section{Notes:}

1. A social group of any size whose members reside in a specific locality, share government, and often have a common cultural and historical heritage.

2. Development has been a mechanism for the production and management of the Third World, organizing the production of truth about the Third World.

3. The festival is celebrated with mela which are called nabanna mela. It is one of the numerous festivals that gave the name "baro mase tero parban" (thirteen festivals in twelve months) to the land of Bengal. 
